\title{
O New Urbanism e o revival escapista de mercado
}

\section{Philip Gunn}

Arquiteto, professor titular da Faculdade de Arquitetura e Urbanismo da USP

não busca idéias novas, mas dá continuidade a precedentes históricos. Com a exceção da acomodação da inovação do século XX referente ao carro, o conjunto de ferramentas para projetos de urbanismo postulado é baseado nos fundamentos tradicionais, flexíveis e orgânicos de autores clássicos como Camillo Sitte e Raymond Unwin. Se seus próprios mentores aceitam que o New Urbanism não é "novo", talvez seja mais adequado falar em um urbanismo reciclado. A repetição dos princípios do passado é vista por seus adeptos como um tema interessante a ser explorado em projetos. Ao lado deste princípio, a Duany Plater-Zyberk e Cia. insiste em dois outros: a universalidade do paradigma e a necessidade de adaptações às condições locais.

No Brasil, uma ampla literatura tem se concentrado na análise de influências, ressonâncias e reverberações de idéias e práticas urbanísticas e de suas condições de adaptação local (Leme, 1999). A aplicação de idéias de Sitte em Santos e no Recife pode ser constatada em obras como o livro do engenheiro Saturnino de Brito, Le Trace Sanitaire des Villes, publicado em 1916 (Brito, 1944), enquanto soluções usadas no bairro-jardim de Hampstead por Unwin e Parker foram utilizadas no Alto da Lapa e no Jardim América, em São Paulo. O desenho cidade-jardim também surge nos trabalhos de Armando de Godoy, em Goiânia, em 1936.

Estados Unidos a partir dos anos 1980, a situação da comunidade dos urbanistas é um pouco mais complicada, pela natureza do fenômeno e, na hipótese de seu possível declínio, pela ausência de uma fórmula corretiva equivalente ao procedimento usado pelos economistas. As dificuldades começam na própria percepção e concepção do fenômeno.

O que fazer quando os próprios mentores de New Urbanism explicam que, de fato, o fenômeno não possui nada de "novo" ? Conforme afirma, em sua entrevista, Galina Tahchieva, diretora da empresa Duany Plater-Zyberk e Cia. de Miami, trata-se de fenômeno baseado em princípios tradicionais, que
Entretanto, a insistência da Duany Plater-Zyberk e Cia. no reconhecimento da necessidade de adaptação às condições do local traz outros problemas, mais nebulosos, de compreensão. O paradoxo retórico do new que não é "novo" parece ser acompanhado por um outro. Em sua entrevista, Galina Tahchieva assinala a necessidade de observar as tradições urbanas do lugar, o ambiente social, a situação econômica e a cultura, antes de traduzir e interpretar estas condições no trabalho de projeto. Entretanto, falta nesse discurso uma visão crítica das possibilidades e metas do projeto urbano diante, 
exatamente, desses condicionantes. Um contraponto, talvez o mais expressivo, a esse discurso no caso dos EUA situa-se nos escritos de Mike Davis no livro City of Quartz. Galina Tahchieva localizou o início do New Urbanism nos primeiros anos da década de 1980, no âmbito de uma reação contra a expansão generalizada dos subúrbios nas grandes aglomerações urbanas. No caso do sul da Califórnia, Davis enfocou o debate sobre essa expansão no contexto de uma enorme valorização imobiliária de terras e moradias suburbanas ocorrida nos anos 1970. Para ele, a vida política local nos subúrbios durante as décadas subseqüentes de 1980 e 90 se centrou nas lutas da classe média suburbana em defesa da valorização imobiliária e pela perpetuação do exclusivismo social criado na era Reagan, com a consolidação dessas comunidades pelos mecanismos de mercado. Davis comenta:

"Bem-vindo à Los Angeles pós-liberal, onde a defesa de estilos de vida de luxo é traduzida pela proliferação de novas formas de repressão no espaço e na mobilidade (...). Esta obsessão por sistemas físicos de segurança e, colateralmente, pelo controle arquitetônico das fronteiras sociais, tornou-se (...) a narrativa mestra do meio construído emergente nos anos noventa. A teoria urbana contemporânea, entretanto, mesmo que debata o papel das tecnologias eletrônicas na precipitação do 'espaço pósmoderno' ou discuta a dispersão das funções urbanas através das 'galáxias' metropolitanas policêntricas, permaneceu estranhamente muda sobre a militarização da vida na cidade..." (Davis, 1990, p. 223).

Compêndios de New Urbanism - como o manual The Lexicon of the New Urbanism da Duany PlaterZyberk e Cia. dos EUA e o Urban Design Compendium da empresa English Partnerships do Reino Unido também são estranhamente mudos no sentido de não possuírem capítulos sobre "segurança" e não fazerem nenhuma menção ou discussão sobre os condicionantes de fechamento e contorno, os quais no Brasil constituem o ponto de partida para projetos de condomínios fechados. Os modelos administrativos de condomínios fechados e controlados aproximam-se, sob este aspecto, de formas arquitetônicas presentes em lugares como a Barra da Tijuca. O funcionalismo modernista do projeto, na maioria dos prédios, expressa um modelo de gestão do controle sobre o ingresso, a saída, a abertura e o fechamento. Há outros exemplos prediais na Barra da Tijuca que não seguem uma estética modernista vinculada ao "estilo internacional". Um exemplo neste sentido é o empreendimento Down Town, baseado em projeto do escritório de Luis Conde arquiteto e depois prefeito de Rio de Janeiro -, que pode ser entendido como um precursor brasileiro do New Urbanism. Nele, aparentemente, há integração com as ruas do bairro: não há barreiras físicas à vista. A escala urbana parece recriar em uma densidade maior a imagem de Venice Beach, em Los Angeles. O nome Down Town, a presença de escritórios nas casas e as conexões de banda larga na web enfatizam a abolição da distância entre a Barra da Tijuca e o centro da cidade. Entretanto, uma tentativa de fotografar suas ruas internas nos revelou de imediato o rígido monitoramento que impõe aos seus usuários: nossas intenções foram averiguadas por ocupantes de carros de segurança, que alertaram que as ruas eram propriedade privada e não podiam ser fotografadas. Em construções erguidas em diferentes estilos, através de mecanismos visíveis ou ocultos, o empenho de controle persiste.

Em tempos reformistas, uma preocupação em nível do projeto urbanístico refere-se às condições de fronteira e à incorporação da cidade ao projeto. Sobre o caso de Los Angeles, Mike Davis lembrou o chamado "enfoque olmsteriano" do espaço público como uma ferramenta para distender os conflitos e a luta entre as classes sociais. O mercado imobiliário e as infra-estruturas de serviços públicos - como avenidas e redes de drenagem - estratificam e separam frações das classes em componentes socialmente homogêneos, conforme já havia indicado Engels escrevendo sobre Londres e sobre os bairros proletários dos irlandeses na cidade de Manchester em meados do século XIX. Segundo Davis, Olmstead concebe parques e áreas verdes como válvulas de segurança, misturando classes sociais e etnias diversas em formas burguesas de lazer e de passatempo. Mas na Los Angeles dos anos 1990, os tempos do reformismo se foram, bem como o empenho na busca de fronteiras transponíveis, porosas e amigáveis. Nela, o papel atribuído às áreas verdes por Olmstead tornou-se tão anacrônico quanto as idéias de John Maynard Keynes sobre pleno emprego (Davis, 1990, p. 227). Nos compêndios da Duany Plater-Zyberk e Cia. e da English Partnerships sobre o New Urbanismo, apesar do uso retórico de palavras referentes a diversidade e mistura, o tema da segregação e da exclusão social é banido da pauta. A atitude escapista diante deste tema não deixa de denunciar uma adesão pouco crítica a uma lógica de mercado e a um modelo de exclusão, oculta na reciclagem de aspectos parciais de fórmulas urbanísticas consagradas. 


\section{Referências bibliográficas}

DAVIS, M. City of quartz. 1. ed. London: Verso, 1990. p. 223.

BRITO, S. de. Urbanismo: traçado sanitário das cidades e estudos diversos. Rio de Janeiro: MEC/Instituto Sanitário das Cidades, 1944. (Obras Completas de Saturnino de Brito, v. XX).

LEME, C. (Coord.). Urbanismo no Brasil 1895-1965. São Paulo: Fupam/Estúdio Nobel, 1999. 